\title{
EAM as a New Conditioning Regimen for Lymphoma Patients Undergoing Autologous Progenitor Cell Transplantation
}

\section{Mohammed Amine Bekadja*}

Hematology and Cell Therapy Department, University Hospital of Oran, Algeria

"Corresponding author: Hematology and Cell Therapy Department, University Hospital of Oran, Algeria, Tel: 00213773844988; Fax: 0021341421636; E-mail: mabekadja@yahoo.fr

Rec date: September 17, 2014 Acc date: September 22, 2014 Pub date: September 24, 2014

Copyright: ( 2014 Bekadja MA, This is an open-access article distributed under the terms of the Creative Commons Attribution License, which permits unrestricted use, distribution, and reproduction in any medium, provided the original author and source are credited.

Keywords: Autologous progenitor cells transplantation; Etoposide; Cytarabine; Melphalan

\section{Editorial}

Autologous progenitor cells transplantation (APCT) after a high dose conditioning chemotherapy is now an established treatment modality for many hematological malignancies such as lymphoma [1] Clinical results and survival after APCT depend on disease chemo sensitivity at transplant and the efficacy of the conditioning regimen at eradicating the residual tumor cell clone [2].

The impact of the conditioning regimen is a controversial matter and despite efforts to identify high-dose regimens with increasing antitumor activity and acceptable toxicity to normal tissues, there is not yet clear evidence of a superior conditioning platform that should be applied in the setting of recurring lymphoma patients, at least in terms of tumor-eradicating capacity.

In lymphoma, the protocols used were of more different type: CBV, BEAM [3], BEAC [4] CEAM [5], FEAM [6] or LACE [7]. CBV and $B E A M$ are the two most frequently used regimens for patients with lymphoma undergoing autologous progenitor cells transplantation (APCT). A BEAM regimen is a widely used conditioning regimen for autologous progenitor cells transplant in patients with Hodgkin lymphoma and non-Hodgkin lymphoma because of its acceptable toxicity and high effectiveness. Adverse events associated with BEAM are related in part to BiCNU [8].

In overall, the outcomes were following: median time to neutrophil $(>500 \times 109 / 1)$ and platelet $(>20,000 \times 109 / 1)$ engraftment was between 11 to 14 days and 13 to 19 days respectively. The mean of the transplant-related mortality (TRM) was between 3 to $7 \%$. The overall survival at 8 years of patients conditioned with BEAM or BEAC (58\%) was more favorable than with CBV $(40 \%)$, and significantly better than with CY-TBI (31\%).

Throughout the years from 2011 to 2012, seventeen patients received the EAM conditioning regimen in our department as follows: Etoposide (total dose of $800 \mathrm{mg} \backslash \mathrm{m}^{2}$ ), Cytarabine (total dose of 8000 $\mathrm{mg} \backslash \mathrm{m}^{2}$ ) and Melphalan $140 \mathrm{mg} / \mathrm{m}^{2}$. The median age was 28 years (range: 17-48). All patients had a full hematopoietic reconstitution.

Median time to achieve neutrophils $>500 / \mu$ l was 13 days (range: 10-19) and median time to achieve an unsupported platelet count
$>20,000 / \mu \mathrm{l}$ was16 days (range: 14-25). Toxicities included grade 4 hematologic in all patients, grade 3 mucositis in 4 , grade 3 infectious in 2. One patient died at 100 -Day (TRM=5,8\%). After a median follow up of 34 months, the overall survival was $67 \%$ at 41 months, 13 patients are alive and 12 are in continuous complete remission.

In conclusion, these data demonstrate the safety and feasibility of EAM regimen as a new and modified regimen. Although these outcomes are encouraging, and comparison with other traditional APCT regimens used for patients with lymphoma is warranted.

\section{References}

1. Gleeson M, Cunningham D, Linch D (2014) The role of myeloablation for lymphoma. N Engl J Med 370: 576.

2. Salar A, Sierra J, Gandarillas M, Caballero MD, Marín J, et al. (2001) Autologous stem cell transplantation for clinically aggressive nonHodgkin's lymphoma: the role of preparative regimens. Bone Marrow Transplant 27: 405-412.

3. Mills W, Chopra R, McMillan A, Pearce R, Linch DC, et al. (1995) BEAM chemotherapy and autologous bone marrow transplantation for patients with relapsed or refractory non-Hodgkin's lymphoma. J Clin Oncol 13: 588-595.

4. Jo JC, Kang BW, Jang G, Sym SJ, Lee SS et al. (2008) BEAC or BEAM highdose chemotherapy followed by autologous stem cell transplantation in non-Hodgkin's lymphoma patients: comparative analysis of efficacy and toxicity. Ann Hematol 87: 43-48.

5. Ramzi M, Mohamadian M, Vojdani R, Dehghani M, Nourani H, et al. (2012) Autologous noncryopreserved hematopoietic stem cell transplant with CEAM as a modified conditioning regimen in patients with Hodgkin lymphoma: a single-center experience with a new protocol. Exp Clin Transplant 10: 163-167.

6. Musso M, Scalone R, Marcacci C, Lanza F, Renzo ND, et al. (2010) Fotemustine plus etoposide, cytarabine and melphalan (FEAM) as a new conditioning regimen for lymphoma patients undergoing auto-SCT: a multicenter feasibility study. Bone Marrow Transplant 45: 1147-1153.

7. Pavlů J, Auner HW, Ellis S, Szydlo RM, Giles C, et al. (2011) LACEconditioned autologous stem cell transplantation for relapsed or refractory diffuse large B-cell lymphoma: treatment outcome and risk factor analysis from a single centre. Hematol Oncol 29: 75-80.

8. Alessandrino EP, Bernasconi P, Colombo A, Caldera D, Martinelli G, et al. (2000) Pulmonary toxicity following carmustine-based preparative regimens and autologous peripheral blood progenitor cell transplantation in hematological malignancies. Bone Marrow Transplant 25: 309-313. 